\title{
Clinically Relevant Drug Interactions in HSCT
}

\author{
Tiene Bauters
}

\subsection{Introduction}

Patients undergoing HSCT often receive polymedication which carries the potential to result in drug interactions. To avoid unexpected outcomes, attention to drug interactions is crucial especially when drugs with a narrow therapeutic index or inherent toxicity profile are involved (Leather 2004; Glotzbecker et al. 2012; Gholaminezhad et al. 2014).

Drug interactions can be defined as changes in a drug's effect due to recent or concurrent use of another drug, food, or environmental agent. The net effect of the combination can result in enhanced activity of the affected drug, possibly leading to toxicity, or reduced activity leading to therapeutic failure (Thanacoody 2012).

In general, drug interactions can be categorized as being pharmacodynamic, pharmacokinetic, or pharmaceutical in nature.

\subsubsection{Pharmacodynamic Interactions}

Pharmacodynamic interactions occur when the effect of one drug is changed by the presence of another drug at its site of action. They compete

T. Bauters $(\bowtie)$

Pharmacy, Pediatric Hemato-Oncology and Stem Cell

Transplantation, Ghent University Hospital,

Ghent, Belgium

e-mail: Tiene.bauters@uzgent.be for specific receptor sites or interfere indirectly with physiological systems.

The effect can be additive/synergistic or antagonistic. An example of an additive interaction is the concurrent use of QT-prolongating drugs (e.g., ciprofloxacin and fluconazole) which substantially increases the risk of torsades de pointes or other ventricular tachyarrhythmias.

Specific antagonists can be used to reverse the effect of another drug at the receptor site (e.g., naloxone, an opioid receptor antagonist which reverses signs of opioid intoxication) (Lexicomp Drug® Interactions 2018).

\subsubsection{Pharmacokinetic Interactions}

Pharmacokinetic interactions (PK) occur when one drug alters the rate or extent of absorption, distribution, metabolism, or elimination of another drug resulting in diminished effects or drug potentiation (Palleria et al. 2013). The most frequent and significant drug interactions relate to drug metabolism. These will be further discussed here.

\subsubsection{Cytochrome P450 Enzyme System}

Several enzyme families are involved in drug metabolism, cytochrome P450 (CYP450) being the most important one. CYP450 consists of a unique group of isoenzymes grouped into families (1-3) and divided into subfamilies (A-E). 
They are primarily found in the liver and are genetically encoded (Ingelman-Sundberg and Rodriguez-Antona 2005; Lynch and Price 2007).

The effect of a CYP450 isoenzyme on a particular substrate can be altered by interaction with other drugs. Drugs can be substrates for a CYP450 isoenzyme and/or may inhibit or induce the isoenzyme (Larson 2018; Glotzbecker et al. 2012; Leather 2004):

Inhibition: Leads to reduced metabolism of the substrate with an increase in the steady-state concentration. It potentiates the effect and might lead to enhanced or toxic effects, especially in drugs with a narrow therapeutic index like cyclosporine and tacrolimus. Its onset occurs within 1-3 days for drugs with a short half-life, while the maximal effect may be delayed for drugs with a long half-life.

Induction: Increases the activity of CYP450 enzymes and usually results in decreased concentration/effect of the affected drug with the risk of therapeutic failure. Since the process of enzyme induction requires new protein synthesis, the effect usually occurs over days to weeks after starting an inducer.

Prodrugs rely on CYP450 enzymes for conversion to their active form(s). The combination of a prodrug (e.g., CFM) with a CYP450 inhibitor may result in therapeutic failure because of little or no production of the active drug. Conversely, an exaggerated therapeutic effect or adverse effect can be expected when a CYP450 inducer is added (Lynch and Price 2007).

In general, any drug metabolized by one of the CYP450 enzymes has the potential for PK- interaction, and concurrent use should be done with caution. As CYP3A4 is responsible for the metabolism of more than $50 \%$ of clinically administered drugs (Ingelman-Sundberg and Rodriguez-Antona 2005; Larson 2018), examples of CYP3A4 substrates, inhibitors, and inducers used in HSCT are presented in Table 31.1.

Mutations in CYP genes give rise to four major phenotypes: poor metabolizers, intermediate metabolizers, extensive metabolizers, and ultrarapid metabolizers (Ingelman-Sundberg and Rodriguez-Antona 2005; Ahmed et al. 2016). Polymorphisms in CYP450 are of concern in the study of interindividual altered drug metabolisms and/or adverse drug reactions.

\subsubsection{Drug Transportation}

P-glycoprotein (PgP) is a plasma membrane transporter involved in the excretion of drugs.

Table 31.1 CYP3A4 substrates, inhibitors and inducers commonly used in HSCT (non-limitative list) (Flockhart 2018; Medicines Complete 2018)

\begin{tabular}{|c|c|c|}
\hline Substrates & Inhibitors & Inducers \\
\hline $\begin{array}{l}\text { Benzodiazepines }^{\mathrm{a}} \\
\text { Budesonide } \\
\text { Calcium Channel Blockers } \\
\text { Carbamazepine } \\
\text { Corticosteroids } \\
\text { Etoposide } \\
\text { Immunosuppressives }{ }^{\mathrm{c}} \\
\text { Macrolide antibiotics }^{\mathrm{d}} \\
\text { Statins }^{\mathrm{e}} \\
\text { Steroids }^{\mathrm{f}} \\
\text { Miscellaneous }^{\mathrm{g}}\end{array}$ & $\begin{array}{l}\text { Amiodarone } \\
\text { Aprepitant } \\
\text { Cimetidine } \\
\text { Ciprofloxacin } \\
\text { Clarithromycin } \\
\text { Diltiazem } \\
\text { Erythromycin } \\
\text { Fluconazole } \\
\text { Grapefruit juice } \\
\text { Itraconazole } \\
\text { Ketoconazole } \\
\text { Posaconazole } \\
\text { Voriconazole } \\
\text { Verapamil }\end{array}$ & $\begin{array}{l}\text { Barbiturates (phenobarbital) } \\
\text { Carbamazepine } \\
\text { Corticosteroids } \\
\text { Phenytoin } \\
\text { Rifampicin } \\
\text { St John's wort }\end{array}$ \\
\hline
\end{tabular}

Bold font indicates strong inhibitors/inducers

aAlprazolam, diazepam, midazolam

${ }^{\mathrm{b}}$ Amlodipine, diltiazem, verapamil

${ }^{\mathrm{c} C y c l o s p o r i n e, ~ t a c r o l i m u s, ~ s i r o l i m u s ~}$

${ }^{\mathrm{d} C l a r i t h r o m y c i n, ~ e r y t h r o m y c i n, ~ N O T ~ a z i t h r o m y c i n ~}$

eAtorvastatin, NOT pravastatin, simvastatin

${ }^{\mathrm{f}}$ Estradiol, progesterone, testosterone

${ }^{\mathrm{g}}$ Aprepitant, fentanyl, ondansetron, thiotepa, zolpidem 
Table 31.2 Drug interactions with busulfan (BU) (non-limitative list) ${ }^{\mathrm{a}}$

\begin{tabular}{|l|l|l|l|}
\hline Interacting drug & $\begin{array}{l}\text { Proposed mechanism } \\
\text { Competition for glutathione }\end{array}$ & $\begin{array}{c}\text { Effect } \\
\text { Increased BU } \\
\text { levels }\end{array}$ & $\begin{array}{l}\text { Recommended action } \\
- \text { Avoid paracetamol within } 72 \text { h prior to or } \\
\text { concurrently with BU } \\
- \text { Monitor for increased BU concentrations/ } \\
\text { toxicity when used concurrently }\end{array}$ \\
\hline Metronidazole & $\begin{array}{l}\text { CYP3A4 inhibition } \\
\text { Competition for glutathione }\end{array}$ & & $\begin{array}{l}\text { - Monitor for increased BU concentrations/ } \\
\text { toxicity when used concurrently }\end{array}$ \\
\hline $\begin{array}{l}\text { Itraconazole } \\
\text { voriconazole }\end{array}$ & $\begin{array}{l}\text { Unclear (probably CYP3A4 } \\
\text { inhibition) }\end{array}$ & & \\
\hline Phenytoin & $\begin{array}{l}\text { CYP3A4/glutathione-S- } \\
\text { transferase induction }\end{array}$ & $\begin{array}{l}\text { Decreased BU } \\
\text { levels }\end{array}$ & - Use alternative antiepileptic (levetiracetam) \\
\hline
\end{tabular}

${ }^{\mathrm{a}}$ Lexicomp ${ }^{\circledR}$ Drug interactions (2018) and Glotzbecker et al. (2012)

Its activity can be inhibited or induced by other drugs, resulting in increased or decreased bioavailability/clearance of $\mathrm{PgP}$ substrates (Ingelman-Sundberg and Rodriguez-Antona 2005; Thanacoody 2012).

\section{Monoclonal Antibodies}

Metabolism of monoclonal antibodies (MABs) does not involve CYP450 enzymes or drug transporters; therefore, PK interactions between MABs and conventional drugs are very limited. However, current information in this area is not abundant and more research is needed (Ferri et al. 2016).

\subsubsection{Pharmaceutical Interactions}

Pharmaceutical interactions manifest when two or more drugs and their diluents are mixed in the same infusion bag/syringe or when infusion lines meet at a Y-site junction. They are the result of incompatibilities as physicochemical reactions (changes in color, turbidimetry, and precipitation). Amphotericin B, for example, should not be diluted or mixed with physiological saline as microprecipitation will occur immediately.

\subsection{Drug Interactions in HSCT Practice}

Drug interactions can occur as early as during the conditioning regimen. Drugs as etoposide and thiotepa rely on CYP450 enzymes for metabolism, while cyclophosphamide needs to be converted to become functional. A non-limitative list of PK interactions with busulfan and recommendations for management are summarized in Table 31.2.

Many clinically relevant interactions have been reported with calcineurin inhibitors (cyclosporine and tacrolimus) and sirolimus. A non-limitative overview of PK interactions with these drugs is presented in Table 31.3.

\subsection{Interactions with Herbal Drugs and Food}

\subsubsection{Herbal Drugs}

The use of herbal drugs is growing worldwide, and a number of serious interactions with conventional drugs have been reported (Enioutina et al. 2017). Patients often do not perceive herbal supplements as drugs and prescribers are not always aware that patients are taking these products. A thorough drug history anamnesis is important and should be performed by asking very specific questions about herbal drug use.

An example of an herbal drug frequently involved in major drug interactions is St John's wort (SJW) (Hypericum perforatum). SJW is an over-the-counter product commonly used in HSCT patients for the treatment of mild depression. SJW can reduce the serum concentration of CYP3A4 substrates as cyclosporine and tacrolimus by induction of CYP3A4 or by increasing $\mathrm{PgP}$ expression, resulting in lack of response. Concomitant use of SJW with drugs metabolized by CYP3A4 should be avoided or monitored if no 
Table 31.3 Pharmacokinetic interactions with cyclosporine (C), tacrolimus (T) and sirolimus (S) (non-limitative list) ${ }^{\mathrm{a}}$

\begin{tabular}{|c|c|c|c|}
\hline Interacting drug & $\begin{array}{l}\text { Proposed } \\
\text { mechanism }\end{array}$ & Effect & Recommended action \\
\hline \multicolumn{4}{|l|}{ Anti-epileptics } \\
\hline $\begin{array}{l}\text { Carbamazepine } \\
\text { Phenobarbital } \\
\text { Phenytoin }\end{array}$ & $\begin{array}{l}\text { CYP3A4 } \\
\text { induction }\end{array}$ & $-\nabla \mathrm{C} / \mathrm{T} / \mathrm{S}$ level & $\begin{array}{l}\text { - Monitor } \mathrm{C} / \mathrm{T} / \mathrm{S} \text { levels } \\
\text { - Increased } \mathrm{C} / \mathrm{T} / \mathrm{S} \text { doses will likely be needed } \\
\text { - Consider therapy modification } \\
\text { (levetiracetam) }\end{array}$ \\
\hline \multicolumn{4}{|l|}{ Antifungals } \\
\hline Caspofungin & Unknown & $\begin{array}{l}\text { - C: } \Delta \text { adverse/toxic effect } \\
\text { of caspofungin } \\
\text { - } \nabla \text { T/S levels }\end{array}$ & $\begin{array}{l}\text { - Monitor liver function/hepatotoxicity in } \\
\text { combination with C } \\
\text { - Monitor T/S levels and adjust as necessary }\end{array}$ \\
\hline $\begin{array}{l}\text { Fluconazole } \\
\text { Itraconazole } \\
\text { Posaconazole } \\
\text { Voriconazole }\end{array}$ & $\begin{array}{l}\text { CYP3A4 and/or } \\
\text { PgP inhibition }\end{array}$ & $-\Delta \mathrm{C} / \mathrm{T} / \mathrm{S}$ levels & $\begin{array}{l}\text { - Monitor clinical response of } \mathrm{C} / \mathrm{T} / \mathrm{S} \text { closely } \\
\text { - Monitor } \mathrm{C} / \mathrm{T} / \mathrm{S} \text { levels closely } \\
\text { - Decreased C/T/S doses will likely be } \\
\text { needed } \\
\text { - Itraconazole: consider therapy modification } \\
(\mathrm{C} / \mathrm{T} / \mathrm{S}) \\
\text { - Posaconazole/voriconazole: consider } \\
\text { therapy modification }(\mathrm{C} / \mathrm{T}) \text {, avoid } \\
\text { combination }(\mathrm{S})\end{array}$ \\
\hline \multicolumn{4}{|c|}{ Calcium channel blockers } \\
\hline $\begin{array}{l}\text { Diltiazem } \\
\text { Verapamil }\end{array}$ & $\begin{array}{l}\text { CYP3A4 } \\
\text { inhibition }\end{array}$ & $-\Delta \mathrm{C} / \mathrm{T} / \mathrm{S}$ levels & $\begin{array}{l}\text { - Monitor C/T/S levels } \\
\text { - Decreased doses of } \mathrm{C} / \mathrm{T} / \mathrm{S} \text { might be needed } \\
\text { - Monitor for decreases in blood pressure }(\mathrm{C}) \\
\text { - Consider therapy modification }(\mathrm{C})\end{array}$ \\
\hline \multicolumn{4}{|c|}{ Calcineurin inhibitors } \\
\hline Cyclosporine & $\begin{array}{l}\text { CYP3A4 } \\
\text { competition }\end{array}$ & $\begin{array}{l}\text { - T: } \triangle \text { levels/nephrotoxicity } \\
\text { of } \mathrm{C} / \mathrm{T} \\
-\mathrm{S}: \Delta \text { levels of S (of specific } \\
\text { concern with modified C) }\end{array}$ & $\begin{array}{l}\text { - Discontinue } \mathrm{C} / \mathrm{T} \text { therapy at least } 24 \mathrm{~h} \text { prior } \\
\text { to initiating therapy with the other agent } \\
\text { - } \mathrm{C} / \mathrm{T} \text { : avoid combination } \\
\text { - Monitor for toxic effects of S } \\
\text { - S: } \triangle \text { risk of C-induced HUS/TTP/TMA } \\
\text { - Administer oral doses of S } 4 \text { h after doses } \\
\text { of C } \\
\text { - } \mathrm{C} / \mathrm{S} \text { : consider therapy modification }\end{array}$ \\
\hline Tacrolimus & & $\begin{array}{l}\text { - } \mathrm{C}: \Delta \text { levels/nephrotoxicity } \\
\text { of } \mathrm{C} / \mathrm{T} \\
\text { - } \mathrm{S}: \Delta \text { adverse/toxic effect } \\
\text { of } \mathrm{T} / \mathrm{S}, \nabla \text { level of } \mathrm{T}\end{array}$ & $\begin{array}{l}\text { Avoid combination with } \mathrm{C} / \mathrm{S} \text { (enhanced } \\
\text { toxicity of } \mathrm{C} / \mathrm{T} / \mathrm{S} \text { ) }\end{array}$ \\
\hline Corticosteroids & $\begin{array}{l}\text { CYP3A4/PgP } \\
\text { induction } \\
\text { CYP3A4 } \\
\text { substrate }\end{array}$ & $\begin{array}{l}-\Delta / \mathrm{C} / \mathrm{T} \text { levels } \\
-\Delta \text { corticosteroid levels }\end{array}$ & $\begin{array}{l}\text { Monitor for changes in C/T levels (likely } \\
\text { initial increase, possibly decrease } \\
\text { thereafter) and toxic effects of } \\
\text { corticosteroids and/or C/T if used } \\
\text { concomitantly }\end{array}$ \\
\hline \multicolumn{4}{|c|}{ Macrolide antibiotics (not azithromycin) } \\
\hline $\begin{array}{l}\text { Clarithromycin } \\
\text { Erythromycin }\end{array}$ & $\begin{array}{l}\text { CYP3A4/PgP } \\
\text { inhibition }\end{array}$ & $\begin{array}{l}-\Delta \mathrm{C} / \mathrm{T} / \mathrm{S} \text { levels } \\
-\mathrm{S}: \Delta \text { level of erythromycin }\end{array}$ & $\begin{array}{l}\text { - Monitor C/T/S levels and adjust dose } \\
\text { accordingly } \\
\text { - Avoid concurrent use }\end{array}$ \\
\hline \multicolumn{4}{|c|}{ Proton pump inhibitors (PPI, not pantoprazole) } \\
\hline $\begin{array}{l}\text { Omeprazole } \\
\text { Lansoprazole }\end{array}$ & $\begin{array}{l}\text { C: unclear } \\
\text { T: CYP3A4/ } \\
\text { CYP2C19 } \\
\text { inhibition }\end{array}$ & $-\Delta \mathrm{C} / \mathrm{T}$ level & $\begin{array}{l}\text { - Monitor } \mathrm{C} / \mathrm{T} \text { levels closely when starting or } \\
\text { stopping therapy with PPI and adjust dosage } \\
\text { if necessary (T) } \\
\text { - Inconsistent data (omeprazole), rabeprazole } \\
\text { or pantoprazole: less likely to significantly } \\
\text { interact }\end{array}$ \\
\hline
\end{tabular}


Table 31.3 (continued)

\begin{tabular}{|c|c|c|c|}
\hline Interacting drug & $\begin{array}{l}\text { Proposed } \\
\text { mechanism }\end{array}$ & Effect & Recommended action \\
\hline \multicolumn{4}{|l|}{ Statins } \\
\hline $\begin{array}{l}\text { Atorvastatin } \\
\text { Simvastatin }\end{array}$ & $\begin{array}{l}\text { CYP3A4 } \\
\text { inhibition and } \\
\text { inhibition of } \\
\text { OATP1B1- } \\
\text { mediated hepatic } \\
\text { uptake }\end{array}$ & $\begin{array}{l}\text { - C: } \triangle \text { level of atorvastatin/ } \\
\text { simvastatin } \\
\text { - T: limited effect }\end{array}$ & $\begin{array}{l}\text { - Monitor for increased risk for statin-related } \\
\text { toxicities (myopathy and rhabdomyolysis) } \\
\text { - C: Avoid concurrent use atorvastatin / } \\
\text { simvastatin } \\
\text { - Consider changing to pravastatin or } \\
\text { fluvastatin (less sensitive to this interaction) } \\
\text { or alternative therapy } \\
\text { - Warn patients to report any unexplained } \\
\text { muscle pains or weakness } \\
\text { - T: No action needed }\end{array}$ \\
\hline \multicolumn{4}{|l|}{ Miscellaneous } \\
\hline Grapefruit juice & $\begin{array}{l}\text { CYP3A4 } \\
\text { inhibition } \\
\text { (intestinal) }\end{array}$ & $\begin{array}{l}-\triangle \mathrm{C} / \mathrm{T} / \mathrm{S} \text { levels }(\mathrm{C} / \mathrm{T} \text { : } \\
\text { primarily limited to orally } \\
\text { administered } \mathrm{C} / \mathrm{T})\end{array}$ & $\begin{array}{l}\text { - Monitor C/T/S levels } \\
\text { - Avoid combination with } \mathrm{C} / \mathrm{S} / \mathrm{T}\end{array}$ \\
\hline Metronidazole & $\begin{array}{l}\text { CYP3A4 } \\
\text { inhibition }\end{array}$ & $-\Delta \mathrm{C} / \mathrm{T} / \mathrm{S}$ levels & - Monitor C/T/S levels \\
\hline $\begin{array}{l}\text { Mycophenolate } \\
\text { mofetil (MMF) }\end{array}$ & $\begin{array}{l}\text { Decreased } \\
\text { enterohepatic } \\
\text { recirculation }\end{array}$ & $\begin{array}{l}\text { - C: } \triangle \text { glucuronide } \\
\text { metabolite concentrations } \\
\text { (associated with } \\
\text { mycophenolate adverse } \\
\text { effects) } \\
\text { - MMF: } \nabla \text { C exposure in } \\
\text { children } \\
\text { - T: does not affect PK of } \\
\text { mycophenolic acid (one } \\
\text { study suggests } \triangle \mathrm{T} \\
\text { exposure) }\end{array}$ & $\begin{array}{l}\text { Monitor MMF dosing and response to } \\
\text { therapy particularly closely when } \\
\text { adjusting concurrent } \mathrm{C} \text { (starting, stopping, } \\
\text { or changing dose) or if changing from } \\
\mathrm{C} \text { to } \mathrm{T} / \mathrm{S}\end{array}$ \\
\hline Rifampicin & $\begin{array}{l}\text { CYP3A4/PgP } \\
\text { induction }\end{array}$ & $-\nabla \mathrm{C} / \mathrm{T} / \mathrm{S}$ levels & $\begin{array}{l}\text { Monitor levels, increase dose } \mathrm{C} / \mathrm{T} / \mathrm{S} \\
\text { accordingly } \\
\text { - Avoid combination if possible }\end{array}$ \\
\hline $\begin{array}{l}\text { St John's wort } \\
\text { (SJW) }\end{array}$ & $\begin{array}{l}\text { CYP3A4/PgP } \\
\text { induction }\end{array}$ & $-\nabla \mathrm{C} / \mathrm{T} / \mathrm{S}$ levels & $\begin{array}{l}\text { - Consider alternatives to SJW } \\
\text { - If it cannot be avoided, monitor } \mathrm{C} / \mathrm{T} / \mathrm{S} \\
\text { levels }\end{array}$ \\
\hline
\end{tabular}

= decreased; $\boldsymbol{\Delta}$ = increased

${ }^{\mathrm{a}}$ Lexicomp ${ }^{\circledR}$ Drug Interactions (2018) and Glotzbecker et al. (2012)

alternative for SJW is available (Enioutina et al. 2017; Lexicomp ${ }^{\circledR}$ Drug Interactions 2018).

\subsubsection{Food}

Drug interactions with food and drinks are known to occur. Grapefruit juice is a potent inhibitor of intestinal CYP3A4, and many clinically relevant interactions have been reported (e.g., with simvastatin and calcineurin inhibitors). Cruciferous vegetables (Brussels sprouts, cabbage, and broccoli) contain substances that are inducers of CYP1A2 but do not appear to cause clinically important drug interactions (Thanacoody 2012).

\subsection{Resources for Drug Interactions}

Drug interactions in HSCT can be numerous. Whenever a potential clinically relevant drug interaction is recognized, a management plan should be recommended (modification in drug therapy or closer monitoring of efficacy and 
adverse reactions) (Tannenbaum and Sheehan 2014). A number of resources are available to help identifying and managing drug interactions (e.g., Lexicomp ${ }^{\circledR}$ Drug Interactions 2018; Clinical Pharmacology ${ }^{\circledR}$ 2018; Medicines Complete $^{\circledR}$ 2018). Interpretation of interactions must be performed carefully to avoid the risk of over-alerting. The patient's clinical status, comorbidities, and severity of the drug interactions presented should always be taken into account.

\subsection{Conclusion}

Drug interactions can occur at all levels during HSCT. Attention to and management of interactions is crucial to prevent severe clinical consequences. Due to the complexity of the therapy and the risk of drug interactions, an active collaboration in a HSCT multidisciplinary team, including physicians, pharmacists, and nurses, is of paramount importance.

\section{Key Points}

- Drug interactions in HSCT are common and can occur at all levels

- Knowledge of mechanisms involved in drug metabolism might help in anticipating interactions

- A multidisciplinary approach is important to reduce the risk of drug interactions

\section{References}

Ahmed S, Zhou Z, Zhou J, Chen SQ. Pharmacogenomics of drug metabolizing enzymes and transporters: relevance to precision medicine. Genomics Proteomics Bioinformatics. 2016;14:298-313.
Clinical Pharmacology powered by ClinicalKey. Tampa: Elsevier. http://www.clinicalkey.com. Accessed 16 Jan 2018.

Enioutina EY, Salis ER, Job KM, Gubarev MI, Krepkova LV, Sherwin CM. Herbal Medicines: challenges in the modern world. Part 5. Status and current directions of complementary and alternative herbal medicine worldwide. Expert Rev Clin Pharmacol. 2017;10:327-38.

Ferri N, Bellosta S, Baldessin L, Boccia D, Racagni G, Corsini A. Pharmacokinetics interactions of monoclonal antibodies. Pharmacol Res. 2016;111:592-9.

Flockhart Table P450 Drug Interactions. Indiana University. http://medicine.iupui.edu/clinpharm/ddis/ main-table/. Accessed 16 Jan 2018.

Gholaminezhad S, Hadjibabaie M, Gholami K, et al. Pattern and associated factors of potential drug-drug interactions in both pre- and early post-hematopoietic stem cell transplantation stages at a referral center in the Middle East. Ann Hematol. 2014;93:1913-22.

Glotzbecker B, Duncan C, Alyea E, Campbell B, Soiffer $\mathrm{R}$. Important drug interactions in hematopoietic stem cell transplantation: what every physician should know. Biol Blood Marrow Transplant. 2012;18: 989-1006.

Ingelman-Sundberg M, Rodriguez-Antona C. Pharmacogenetics of drug-metabolizing enzymes: implications for a safer and more effective drug therapy. Philos Trans R Soc Lond B Biol Sci. 2005;360:1563-70.

Larson AM. Drugs and the liver: metabolism and mechanisms of injury. UpToDate, Post TW (Ed), UpToDate, Waltham, MA. Accessed 16 Jan 2018.

Leather HL. Drug interactions in the hematopoietic stem cell transplant (HSCT) recipient: what every transplanter needs to know. Bone Marrow Transplant. 2004;33:137-52.

Lexicomp Drug Interactions. UpToDate, Post TW (Ed), UpToDate, Waltham, MA. Accessed 16 Jan 2018.

Lynch T, Price A. The effect of cytochrome P450 metabolism on drug response, interactions, and adverse effects. Am Fam Physician. 2007;76:391-6.

MedicinesComplete [online]. London: Pharmaceutical Press. http://www.medicinescomplete.com/. Accessed 16 Jan 2018.

Palleria C, Di Paolo A, Giofrè C, et al. Pharmacokinetic drug-drug interaction and their implication in clinical management. J Res Med Sci. 2013;18:601-10.

Tannenbaum C, Sheehan NL. Understanding and preventing drug-drug and drug-gene interactions. Expert Rev Clin Pharmacol. 2014;7:533-44.

Thanacoody HKR. Drug interactions. In: Walker R, Whittlesea C, editors. Clinical pharmacy and therapeutics. 5th ed. London: Elsevier; 2012. 
Open Access This chapter is licensed under the terms of the Creative Commons Attribution 4.0 International License (http://creativecommons.org/licenses/by/4.0/), which permits use, sharing, adaptation, distribution and reproduction in any medium or format, as long as you give appropriate credit to the original author(s) and the source, provide a link to the Creative Commons license and indicate if changes were made.

The images or other third party material in this chapter are included in the chapter's Creative Commons license, unless indicated otherwise in a credit line to the material. If material is not included in the chapter's Creative Commons license and your intended use is not permitted by statutory regulation or exceeds the permitted use, you will need to obtain permission directly from the copyright holder.

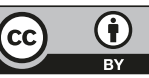

